\title{
Alkaloid Extract of Moringa oleifera Lam. Exerts Antitumor Activity in Human Non-Small-Cell Lung Cancer via Modulation of the JAK2/STAT3 Signaling Pathway
}

\author{
Jing Xie, ${ }^{1,2}$ Lin-jie Peng, ${ }^{1,2}$ Ming-rong Yang, ${ }^{1,3}$ Wei-wei Jiang, ${ }^{3}$ Jia-ying Mao,, 3 \\ Chong-ying Shi, ${ }^{1}$ Yang Tian $\mathbb{1}{ }^{1,2}$ and Jun Sheng $\mathbb{1}^{4}$ \\ ${ }^{1}$ College of Food Science and Technology, Yunnan Agricultural University, Kunming 650224, China \\ ${ }^{2}$ Engineering Research Center of Development and Utilization of Food and Drug Homologous Resources, Ministry of Education, \\ Yunnan Agricultural University, Kunming 650224, China \\ ${ }^{3}$ National Research and Development Professional Center for Moringa Processing Technology, Yunnan Agricultural University, \\ Kunming 650224, China \\ ${ }^{4}$ Key Laboratory of Pu-er Tea Science, Ministry of Education, Yunnan Agricultural University, Kunming 650224, China
}

Correspondence should be addressed to Yang Tian; tianyang1208@163.com and Jun Sheng; shengjun_ynau@163.com

Received 8 January 2021; Revised 12 April 2021; Accepted 19 May 2021; Published 9 June 2021

Academic Editor: Benoit Banga N'guessan

Copyright ( $\odot 2021$ Jing Xie et al. This is an open access article distributed under the Creative Commons Attribution License, which permits unrestricted use, distribution, and reproduction in any medium, provided the original work is properly cited.

\begin{abstract}
Lung cancer is one of the most common malignant tumors diagnosed worldwide. Moringa oleifera Lam. is a valuable medicinal plant native to India and Pakistan. However, the antilung cancer activity of M. oleifera alkaloid extract (MOAE) is unknown. The present study aimed to evaluate the regulatory effect of MOAE on A549 cells by examination of the proliferation, apoptosis, cell cycle, and migration of cells and to elucidate the possible mechanism of action of MOAE. We tested five types of cancer cells and four types of lung cancer cells and found MOAE exerted the strongest growth inhibitory effect against A549 cells but had low toxicity to GES-1 cells (human gastric mucosal epithelial cells). Simultaneously, MOAE induced apoptosis and increased the expression of the apoptosis-related proteins caspase-3 and caspase-9 in A549 cells. Furthermore, MOAE induced cell cycle arrest in the $S$ phase through a decrease in the expression of the proteins cyclin D1 and cyclin E and an increase in the expression of the protein p21. MOAE also inhibited the migratory ability of A549 cells and decreased the expression of the migration-related proteins, matrix metalloproteinase (MMP) 2 and MMP9. In addition, the phosphorylation level of JAK2 and STAT3 proteins was decreased in MOAE-treated A549 cells. Furthermore, AZD1480 (a JAK inhibitor) and MOAE inhibited the proliferation and migration of A549 cells and induced cell apoptosis, and the effects of MOAE and AZD1480 were not additive. These results indicated that MOAE inhibits the proliferation and migration of A549 cells and induces apoptosis and cell cycle arrest through a mechanism that is related to the inhibition of JAK2/STAT3 pathway activation. Thus, this extract has potential for preventing and treating lung cancer.
\end{abstract}

\section{Introduction}

Non-small-cell lung cancer (NSCLC) comprises approximately $80 \%$ of cancers globally and is associated with the highest morbidity and mortality of all malignant tumors $[1,2]$. Despite the progress achieved through the optimization of surgical methods, adjuvant therapy, and comprehensive multimodal therapy, the treatment outcomes and prognosis of patients with NSCLC, especially those with advanced disease, remain unsatisfactory. In addition, existing treatments and drugs are accompanied by serious adverse reactions that significantly reduce the quality of life of the patients [3]. Therefore, to improve the effects of therapy and to increase overall patient survival, new agents with minimal side effects and good treatment efficacy must be identified.

Moringa oleifera Lam. (Moringaceae), also known as the drumstick tree, is a tropical and subtropical plant known 
colloquially as the "miracle tree" owing to its rich nutritional and medicinal value. M. oleifera extracts possess anti-inflammatory [4], cardioprotective [5], hypocholesterolemic [6], antidiabetic [7], antihypertensive [8, 9], neuroprotective [10], hepatoprotective [11], antioxidant [12], and antibacterial properties [13], among others. Additionally, various parts of the M. oleifera plant, including the leaves, stem bark, fruit pods, and seeds, have growth inhibitory effects in various types of tumor cells, including lung cancer [14], liver cancer [15], leukemia [16], pancreatic cancer [17], and cervical cancer [18].

Alkaloids are a class of nitrogen-containing organic alkaline compounds with analgesic, spasm-relieving, antibacterial, anti-inflammatory, hypotensive, antiasthmatic, and antitumoral properties [19]. As many alkaloids are highefficiency and low-toxicity antitumoral compounds, their potential use as cancer treatment has attracted the attention of researchers worldwide. More than 200 compounds have been isolated from the flowers, roots, leaves, and fruits of M. oleifera. Among them, the alkaloids $N, \alpha$-L-rhamnopyranosyl vincosamide, $N$-benzylcarbamic acid, deoxyniazimicin, 3-dibenzyl urea, and aurantiamide acetate have been reported to exert protective effects against cardiovascular diseases and to participate in the removal of free radicals $[5,20,21]$. However, the antilung cancer activity of M. oleifera alkaloids has not been confirmed.

The aim of the present study was to evaluate the regulatory effect of $M$. oleifera alkaloid extract (MOAE) on NSCLC A549 cells by evaluating the proliferation, apoptosis, cell cycle, and migration of cells and to elucidate the possible mechanism of action of MOAE.

\section{Materials and Methods}

2.1. Separation and Extraction of M. oleifera Alkaloids. Alkaloids were prepared as described previously [22]. In brief, M. oleifera leaf powder $(10 \mathrm{~kg}$; Yunnan Tianyou Technology Development Co., Ltd., Dehong, Yunnan, China) was extracted three times with $50 \%$ ethanol, and the extracts were filtered and combined. The combined ethanol extracts were then concentrated using a rotary evaporator at $50^{\circ} \mathrm{C}$. The concentrated extracts were adjusted to $\mathrm{pH} 2$ by the addition of $10 \% \mathrm{HCl}$ and extracted three times with ethyl acetate. The extracts were combined and concentrated with a rotary evaporator to remove ethyl acetate. The acidic aqueous solution was adjusted to $\mathrm{pH} 10$ with sodium hydroxide and then extracted three times with chloroform. The extracts were combined and concentrated with a rotary evaporator to remove chloroform; finally, $30 \mathrm{~g}$ of alkaloid extract was obtained.

2.2. LTQ-Orbitrap High-Resolution Mass Spectrometry Analysis of MOAE. The composition of the MOAE was analyzed using an LTQ-Orbitrap linear ion trap-tandem electrostatic field orbital trap high-resolution mass spectrometer (Thermo Fisher, Waltham, MA, USA) equipped with an FTZ Orbitrap mass detector and an electrospray ion source (ESI). The mass scanning range was
$100-1,000 \mathrm{~m} / z$, the spray voltage was $4.0 \mathrm{kV}$, the tubular lens voltage was $110 \mathrm{~V}$, the capillary temperature was $350^{\circ} \mathrm{C}$, the sheath gas flow was $30 \mathrm{~L} / \mathrm{h}$, and the auxiliary gas flow was $10 \mathrm{~L} / \mathrm{h}$. The instrument was operated in positive mode, and the resolution was set to 30,000. Data-dependent scanning was used for the analysis of secondary and tertiary peaks, and the three peaks with the highest abundance were selected for collision-induced dissociation (CID) and fragment scanning. Fragment ions were detected using an ion trap.

2.3. Cell Culture. A549, HCT116, A375, MDA-MB-231, Hep-G2, NCI-H1975, NCI-H1781, NCI-H441, and GES-1 cells were purchased from the Kunming Institute of Zoology, Chinese Academy of Sciences. The cells were cultured in DMEM/F12 medium, RPMI 1640 medium, or DMEM highglucose medium (HyClone, CA, USA), as appropriate, containing $10 \%$ fetal bovine serum (HyClone), $1 \%$ of $1 \mathrm{~g} / \mathrm{mL}$ streptomycin, and $1000 \mathrm{U} / \mathrm{mL}$ penicillin (Solarbio, Beijing, China), at $37^{\circ} \mathrm{C}$ in a humidified incubator with an atmosphere containing $5 \% \mathrm{CO}_{2}$.

2.4. MTT Assay. A549, HCT116, A375, MDA-MB-231, and Hep-G2 cells in the logarithmic growth phase were seeded in 96-well plates $\left(1 \times 10^{4}\right.$ cells/well), cultured at $37^{\circ} \mathrm{C}$ in a humidified incubator with an atmosphere containing 5\% $\mathrm{CO}_{2}$ for $12-24 \mathrm{~h}$, and then treated with different concentrations of MOAE $(0,25,50,100,200$, or $400 \mu \mathrm{g} / \mathrm{mL})$ for $48 \mathrm{~h}$. The control cells were treated with $0.1 \%$ DMSO. After $48 \mathrm{~h}$, the supernatant was removed, and $100 \mu \mathrm{L}$ of MTT solution $(0.25 \mathrm{mg} / \mathrm{mL})$ was added to each well. After incubation for $4 \mathrm{~h}$, the supernatant was removed and $200 \mu \mathrm{L}$ of DMSO was added to each well. The cells were shaken for $10 \mathrm{~min}$ to ensure complete dissolution of the purple crystals, and the absorbance at $490 \mathrm{~nm}$ was then measured. The $\mathrm{IC}_{50}$ value (the concentration of the drug capable of causing $50 \%$ inhibition of cell survival) was calculated using SPSS software.

A549, NCI-H1975, NCI-H1781, NCI-H441, and GES-1 cells $\left(1 \times 10^{4}\right.$ cells/well $)$ were seeded in 96 -well plates for $24 \mathrm{~h}$ and treated with $\operatorname{MOAE}(0,100,200,400$, or $800 \mu \mathrm{g} / \mathrm{mL})$ for $24 \mathrm{~h}$ or $48 \mathrm{~h}$. After $24 \mathrm{~h}$ and $48 \mathrm{~h}$, the cell viability was evaluated by the MTT assay.

A549 cells $\left(1 \times 10^{4}\right.$ cells/well $)$ were seeded in 96-well plates for $24 \mathrm{~h}$. The cells were pretreated with the JAK inhibitor AZD1480 $(2.5 \mu \mathrm{M})$ (Selleck Chemicals, Houston, TX, USA) for $2 \mathrm{~h}$, then treated with MOAE $(0$ or $200 \mu \mathrm{g} / \mathrm{mL})$ for $48 \mathrm{~h}$. After $48 \mathrm{~h}$, the cell viability was evaluated by the MTT assay.

2.5. Observation of Cell Morphology. A549 cells were seeded in $60 \mathrm{~mm}$ culture plates at a density of $1 \times 10^{6}$ cells/plate and left to adhere. $\operatorname{MOAE}(0,100$, or $200 \mu \mathrm{g} / \mathrm{mL})$ treatment was applied for $48 \mathrm{~h}$. The supernatant was then removed, fresh culture medium was added, and cell morphology was observed under an inverted microscope. 
2.6. Colony Formation Assay. The colony formation assay was conducted as previously described [23]. A549 cells were seeded in 6-well plates at a density of 500 cells/well, cultured at $37^{\circ} \mathrm{C}$ in a humidified incubator with an atmosphere containing $5 \% \mathrm{CO}_{2}$ for $12-24 \mathrm{~h}$, and then treated with different concentrations of $\operatorname{MOAE}(0,100$, or $200 \mu \mathrm{g} / \mathrm{mL})$ for $48 \mathrm{~h}$. Subsequently, the culture medium was replaced with fresh medium, and the cells were cultured for a further 15 days. Then, the cells were fixed in methanol and stained with $0.1 \%$ crystal violet for $15 \mathrm{~min}$. After staining, the cells were washed several times with PBS, and the plates were air-dried and imaged. The crystal violet stain was dissolved in $10 \%$ glacial acetic acid, and the absorbance at $560 \mathrm{~nm}$ was measured.

2.7. Cell Apoptosis and Cell Cycle Analysis. Flow cytometry was performed as previously described [24]. To analyze apoptosis, A549 cells were first seeded in 6-well plates $\left(1 \times 10^{6}\right.$ cells/plate) and treated with $\operatorname{MOAE}(0,100$, or $200 \mu \mathrm{g} / \mathrm{mL}$ ) for $48 \mathrm{~h}$. Then, the cells were collected, washed twice with precooled PBS, and centrifuged. Binding buffer $(100 \mu \mathrm{L})$ containing $5 \mu \mathrm{L}$ of Annexin V/fluorescein isothiocyanate (FITC) and $10 \mu \mathrm{L}$ of $20 \mathrm{mg} / \mathrm{mL}$ propidium iodide (PI; Sigma-Aldrich, Germany) was added to the cells, which were incubated for $10-15 \mathrm{~min}$ and then analyzed by flow cytometry (BD FACSCalibur, CA, USA) within $1 \mathrm{~h}$.

A549 cells $\left(1 \times 10^{6}\right.$ cells/plate $)$ were seeded in 6-well plates for $24 \mathrm{~h}$. The cells were pretreated with the JAK inhibitor AZD1480 $(2.5 \mu \mathrm{M})$ for $2 \mathrm{~h}$ and then treated with MOAE ( 0 or $200 \mu \mathrm{g} / \mathrm{mL}$ ) for $48 \mathrm{~h}$. After $48 \mathrm{~h}$, cell apoptosis was measured as described above.

For cell cycle analysis, A549 cells were harvested as above, washed twice with precooled PBS, fixed in $70 \%$ ethanol, and placed in a refrigerator at $4^{\circ} \mathrm{C}$ overnight. After washing with PBS, $500 \mu \mathrm{L}$ of RNase/PI dye was added to the cells, which were incubated for $30 \mathrm{~min}$ and then analyzed by flow cytometry within $1 \mathrm{~h}$.

2.8. Western Blotting Assay. Western blotting was performed as previously described [25]. A549 cells were seeded in $60 \mathrm{~mm}$ culture plates $\left(1 \times 10^{6}\right.$ cells/plate $)$ and treated with MOAE $(0,100$, or $200 \mu \mathrm{g} / \mathrm{mL})$ for $48 \mathrm{~h}$. Total protein was extracted from A549 cells using RIPA buffer containing phenylmethylsulfonyl fluoride (PMSF) (RIPA : $\mathrm{PMSF}=100$ : $1)$. The proteins were separated by $10 \%$ SDS-PAGE, transferred to polyvinylidene fluoride (PVDF) membranes, and then blocked with 5\% skimmed milk powder at room temperature for $1 \mathrm{~h}$ to prevent nonspecific binding. The membranes were incubated overnight at $4^{\circ} \mathrm{C}$ with primary antibodies against caspase-3, caspase-9, cyclin D1, cyclin E (Santa Cruz mouse monoclonal antibodies; catalog numbers sc-7272, sc-56076, sc-8396, and sc-247, respectively; all 1 : 1000 dilution), p21, MMP2, MMP9 (Abcam rabbit monoclonal antibodies; catalog numbers ab109520, ab92536, and ab76003, respectively; all 1:2000 dilution), JAK2, p-JAK2, STAT3, p-STAT3, and $\beta$-actin (Cell Signaling Technology rabbit monoclonal or polyclonal antibodies; catalog numbers 12640, 9145, 3230, 3771, and 4970, respectively; $1: 2000$ dilution). The membranes were washed three times with PBST and incubated with horseradish peroxidase-conjugated goat anti-rabbit/anti-mouse secondary antibody ( $1: 5,000$; R\&D Systems, USA) for $1 \mathrm{~h}$. After a further three washes with PBST, the protein bands were detected by chemiluminescence and analyzed using ImageJ and GraphPad Prism 5.

2.9. Wound Healing Assay. A549 cells $\left(1 \times 10^{6}\right.$ cells/plate $)$ were seeded in $60 \mathrm{~mm}$ culture plates and allowed to adhere. A sterile pipette tip was used to generate a scratch across the cell layer, which was then imaged using an inverted microscope [26]. The cells were subjected to treatment (either pretreatment with the JAK inhibitor AZD1480 $(2.5 \mu \mathrm{M})$ for $2 \mathrm{~h}$ and then treatment with MOAE $(0$ or $200 \mu \mathrm{g} / \mathrm{mL})$ or only MOAE (0 or $200 \mu \mathrm{g} / \mathrm{mL})$ ) for $48 \mathrm{~h}$ and imaged again. The results were analyzed using ImageJ and GraphPad Prism 5.

2.10. Transwell Migration Assay. Cell migration through Transwell filters was analyzed as previously described [27]. The migratory ability of A549 cells was examined using 24well Transwell plates with $8 \mu \mathrm{m}$ pore membrane inserts (Corning, NY, USA). Cell suspensions $\left(200 \mu \mathrm{L}\left(2 \times 10^{4}\right.\right.$ cells) in serum-free medium) containing different concentrations of $\operatorname{MOAE}(0,100$, or $200 \mu \mathrm{g} / \mathrm{mL})$ were added to the upper chamber of the Transwell plates. Then, $600 \mu \mathrm{L}$ of complete medium containing $10 \%$ FBS was added to the lower chamber, and the cells were incubated at $37^{\circ} \mathrm{C}$ for $48 \mathrm{~h}$. Noninvading cells in the upper chamber were removed with a cotton swab. The migrated cells were fixed in methanol, stained with crystal violet, and observed and photographed under a microscope. The number of migrated cells was counted using a hemocytometer.

2.11. Statistical Analysis. Data presented as bar graphs show the mean \pm standard error of the mean (SEM) of at least three independent experiments. The statistical significance of data was evaluated using one-way ANOVA analysis of variance by GraphPad software. For data not conforming to a normal distribution and equal variance, nonparametric tests were used. $p$ values of $<0.05,<0.01$, or $<0.001$ were considered to indicate a statistically significant difference.

\section{Results}

3.1. MOAE Inhibited the Proliferation of A549 Cells. To investigate the antitumor activity of MOAE, we evaluated the growth inhibitory effect of MOAE on A549, A375, HCT116, MDA-MB-231, and Hep-G2 cells by the MTT assay. MOAE significantly inhibited the growth of A549 cells in a concentration-dependent manner. The $\mathrm{IC}_{50}$ of MOAE in A549, A375, HCT116, Hep-G2, and MDA-MB-231 cells was $158.67 \mu \mathrm{g} / \mathrm{mL}, 238.61 \mu \mathrm{g} / \mathrm{mL}, 276.96 \mu \mathrm{g} / \mathrm{mL}, 283.07 \mu \mathrm{g} / \mathrm{mL}$, and $413.13 \mu \mathrm{g} / \mathrm{mL}$, respectively (Figure $1(\mathrm{a})$ ). As a further investigation of the effect of MOAE on the growth of different lung cancer cells, A549, NCI-H1975, NCI-H1781, and NCI-H441 cells were treated with $\operatorname{MOAE}(0,100,200,400$, 


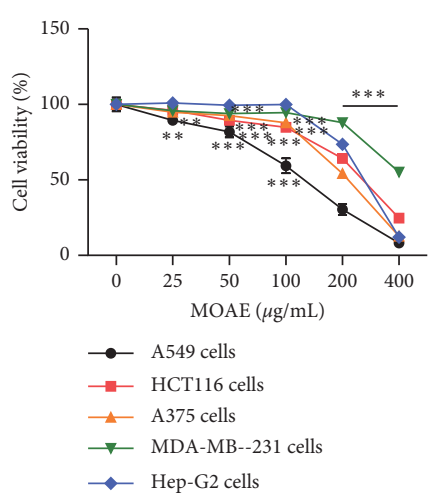

(a)

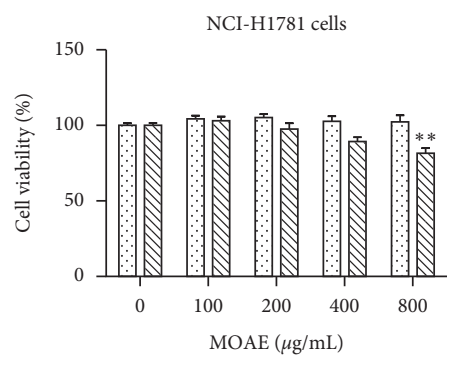

$24 \mathrm{~h}$

ए $48 \mathrm{~h}$

(d)

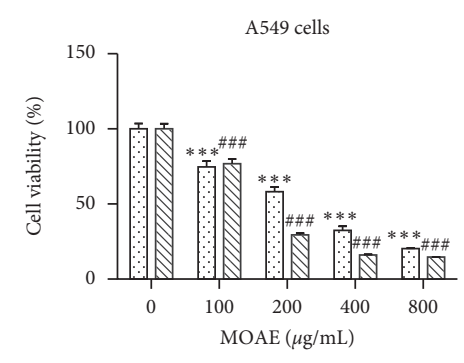

$\varpi 24 \mathrm{~h}$

ه $48 \mathrm{~h}$

(b)

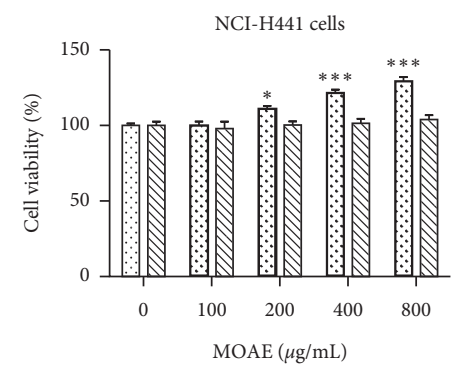

๑24h

四 $48 \mathrm{~h}$

(e)

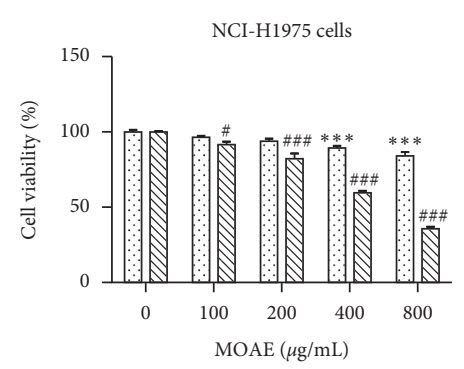

$$
24 \mathrm{~h}
$$$$
\square 4 \mathrm{~h}
$$

(c)

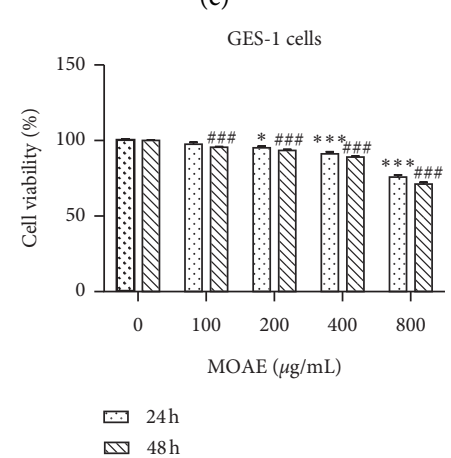

(f)

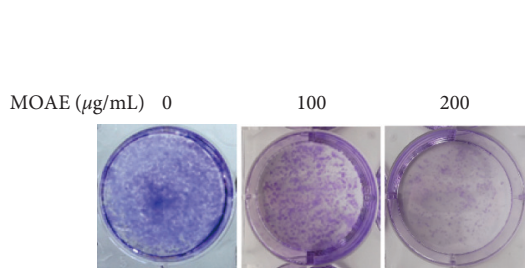

(g)

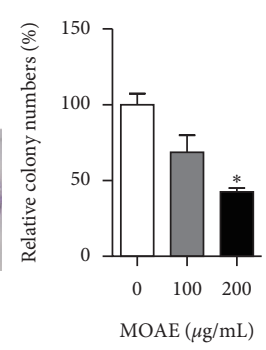

$\operatorname{MOAE}(\mu \mathrm{g} / \mathrm{mL}) \quad 0$
100

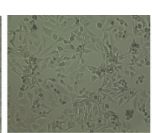

200

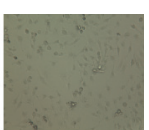

(h)

FIGURE 1: MOAE inhibits the proliferation of A549 cells. (a) The relative viability of A549, A375, HCT116, Hep-G2, and MDA-MB-231 cells following MOAE $(0-400 \mu \mathrm{g} / \mathrm{mL})$ treatment for $48 \mathrm{~h}$. ${ }^{* *} p<0.01$ and ${ }^{* * *} p<0.001 v s .0 \mu \mathrm{g} / \mathrm{mL}$. The relative cell viability of A549 (b), NCIH1975 (c), NCI-H1781 (d), NCI-H441 (e), and GES-1 (f) cells following MOAE $(0-800 \mu \mathrm{g} / \mathrm{mL})$ treatment for $24 \mathrm{~h}$ or $48 \mathrm{~h} .{ }^{*} p<0.05$, ${ }^{* *} p<0.01$, and ${ }^{* * *} p<0.001$ vs. $0 \mu \mathrm{g} / \mathrm{mL}$ at $24 \mathrm{~h} ;{ }^{\#} p<0.05$ and ${ }^{\# \# \#} p<0.001 \mathrm{vs} .0 \mu \mathrm{g} / \mathrm{mL}$ at $48 \mathrm{~h}$. (g) The relative number of colonies of A549 cells after MOAE treatment $(0,100$, or $200 \mu \mathrm{g} / \mathrm{mL})$ for $48 \mathrm{~h} .{ }^{*} p<0.05 v s .0 \mu \mathrm{g} / \mathrm{mL}$. (h) The morphological changes in A549 cells after treatment with different concentrations of $\operatorname{MOAE}(0,100$, or $200 \mu \mathrm{g} / \mathrm{mL})$ for $48 \mathrm{~h}$. The results are expressed as the mean \pm SEM of three independent experiments.

or $800 \mu \mathrm{g} / \mathrm{mL}$ ) for $24 \mathrm{~h}$ or $48 \mathrm{~h}$. Compared with the control, MOAE significantly inhibited the proliferation of A549 and NCI-H1975 cells in a concentration- and time-dependent manner (Figures 1(b) and 1(c)). MOAE had the most significant inhibitory effect on A549 cells. In addition, MOAE was found to have no inhibitory effect on the growth of NCIH1781 and NCI-H441 cells (Figures 1(d) and 1(e)). To determine whether MOAE was toxic to normal cells, we evaluated the effect of MOAE on the growth of GES-1 cells by the MTT assay. We found that for an MOAE dose of $800 \mu \mathrm{g} / \mathrm{mL}$, the cell survival percentage at $24 \mathrm{~h}$ and $48 \mathrm{~h}$ was $75.76 \%$ and $71.15 \%$, respectively (Figure $1(\mathrm{f})$ ). These results indicated that MOAE had the strongest growth inhibitory effect on A549 cells but had low toxicity to GES-1 cells.
In addition, at $48 \mathrm{~h}, \mathrm{MOAE}$ treatment also reduced the clone-formation rate of A549 cells compared with the control group, from $100 \% \pm 7.37 \%(0 \mu \mathrm{g} / \mathrm{mL})$ to $68.69 \% \pm 11.23 \%$ and $42.57 \% \pm 2.39 \%(100$ and $200 \mu \mathrm{g} / \mathrm{mL}$ MOAE, respectively) (Figure $1(\mathrm{~g})$ ). Moreover, unlike the control cells that were polygonal in shape and tightly arranged, MOAE-treated A549 cells were loosely arranged and were further apart, and some cells were observed to shrink and dissolve (Figure 1(h)). Collectively, these results showed that MOAE could inhibit the growth of A549 cells.

3.2. MOAE Induced A549 Cell Apoptosis. As MOAE-treated A549 cells exhibited apoptotic characteristics, we assessed 
cell apoptosis by flow cytometry. As shown in Figures 2(a) and 2(b), compared with the control cells (3.62\% $\pm 0.24 \%)$, the percentage of apoptotic cells was higher following 100 and $200 \mu \mathrm{g} / \mathrm{mL}$ MOAE treatment at $13.63 \% \pm 0.43 \%$ and $35.89 \% \pm 1.38 \%$, respectively. Furthermore, MOAE treatment at $200 \mu \mathrm{g} / \mathrm{mL}$ led to a significant increase in the expression of the apoptosis marker proteins caspase- 3 $(p<0.01)$ and caspase-9 $(p<0.05)$ (Figure $2(c))$. These results indicated that MOAE induced caspase-dependent apoptosis in A549 cells.

3.3. MOAE Induced Cell Cycle Arrest. To determine the effect of MOAE on the cell cycle, we examined the cell cycle of A549 cells by flow cytometry. The proportion of cells in the G1 phase was significantly reduced, and the proportion of cells in the $S$ phase was significantly increased in a MOAE concentration-dependent manner. The percentage of A549 cells in the G1 phase decreased from $90.44 \% \pm 0.63 \%(0 \mu \mathrm{g} /$ $\mathrm{mL}$ ) to $82.03 \% \pm 0.73 \%$ and $69.56 \% \pm 1.29 \%$, respectively, whereas the percentage of A549 cells in the S phase increased from $5.16 \% \pm 0.76 \%$ to $12.66 \% \pm 0.48 \%$ and $19.39 \% \pm 1.42 \%$, respectively, after treatment with MOAE (100 and $200 \mu \mathrm{g} /$ $\mathrm{mL}$ ) (Figures 3(a) and 3(b)). We then measured the expression levels of cell cycle-related proteins by western blotting. As shown in Figure 3(c), compared with the control group, MOAE treatment at $200 \mu \mathrm{g} / \mathrm{mL}$ decreased the expression of cyclin D1 $(p<0.05)$ and cyclin E but increased the expression of p21 $(p<0.01)$ (Figure 3(c)). These results indicated that MOAE induced cell cycle arrest in A549 cells and modulated the expression of cell cycle-related proteins.

3.4. MOAE Inhibited A549 Cell Migration. To investigate the inhibitory effect of MOAE on the migratory ability of A549 cells, we analyzed the migration rate of cells by wound healing and Transwell migration assays. Wound healing in A549 cells was significantly inhibited by MOAE in a concentration-dependent manner. Compared with the control group $(100 \% \pm 3.01 \%)$, the wound-healing rate decreased to $25.45 \% \pm 3.75 \%$ and $15.18 \% \pm 2.74 \%$, following MOAE treatment at $100 \mu \mathrm{g} / \mathrm{mL}$ and $200 \mu \mathrm{g} / \mathrm{mL}$, respectively (Figure 4(a)). Moreover, the cell migration rate was decreased from $100 \% \pm 5.89 \%$ to $74.60 \% \pm 2.60 \%$ and $44.41 \% \pm 0.42 \%$, respectively (Figure $4(\mathrm{~b})$ ). Western blotting assay results showed that, compared with controls, MOAE treatment at $200 \mu \mathrm{g} / \mathrm{mL}$ inhibited the expression of the cell migration-related proteins MMP2 $(p<0.05)$ and MMP9 in A549 cells in a concentration-dependent manner (Figure 4(c)). Together, these results indicated that MOAE could inhibit A549 cell migration by regulating the expression of migration-related proteins.

3.5. MOAE Inhibited the Activation of the JAK2/STAT3 Signaling Pathway in A549 Cells. Studies have shown that the Janus kinase 2/signal transducer and activator of transcription 3 (JAK2/STAT3) signaling pathway is overactive in NSCLC tissues and is closely associated with proliferation, angiogenesis, invasion, and migration of NSCLC cells [28].
To verify the inhibitory effect of MOAE on the JAK2/STAT3 signaling pathway in A549 cells, we evaluated the protein expression of JAK2, p-JAK2, STAT3, and p-STAT3 by western blotting assay. As shown in Figures 5(a) and 5(b), MOAE $(200 \mu \mathrm{g} / \mathrm{mL})$ significantly inhibited the expression of p-JAK2 $(p<0.01)$ and p-STAT3 $(p<0.01)$ in a concentration-dependent manner. To determine the specific roles of JAK in the MOAE-mediated inhibition of cell growth and migration and induction of apoptosis, the cells were pretreated for $2 \mathrm{~h}$ with AZD1480 (a JAK inhibitor). Consistent with previous results, a significant decrease in cell viability and migration and an increase in apoptosis were observed in MOAE-treated A549 cells. Similarly, after pretreatment with AZD1480, cell viability and migration were significantly decreased, and apoptosis was significantly increased. However, AZD1480 and MOAE had no synergistic effect on proliferation, migration, and apoptosis in A549 cells (Figures 5(c)-5(e)). These results indicated that MOAE inhibits cell proliferation and migration and induces cell apoptosis through inhibition of the activation of JAK2/ STAT3 signaling pathway.

3.6. Analysis of the Chemical Constituents of MOAE Using LTQ-Orbitrap Mass Spectrometry. Five compounds $\left(\mathrm{C}_{28} \mathrm{H}_{38} \mathrm{~N}_{2} \mathrm{O}_{12}, \mathrm{C}_{27} \mathrm{H}_{36} \mathrm{~N}_{2} \mathrm{O}_{11}, \mathrm{C}_{23} \mathrm{H}_{31} \mathrm{NO}_{7}, \mathrm{C}_{19} \mathrm{H}_{24} \mathrm{~N}_{2} \mathrm{O}_{13}\right.$, and $\mathrm{C}_{22} \mathrm{H}_{32} \mathrm{~N}_{4} \mathrm{O}_{6}$ ) were identified using LTQ-Orbitrap highresolution mass spectrometry. The retention times of the five compounds were 4.53-4.55, 7.17-7.18, 7.67-7.70, 8.75-8.77, and $11.24-11.26 \mathrm{~min}$, respectively. The molecular masses of these analytes were 594.2425, 564.2319, 433.2101, 488.1278, and $448.2322 \mathrm{~g} / \mathrm{mol}$, respectively (Figure 6).

\section{Discussion}

M. oleifera possesses a variety of pharmacological properties; the most prominent is its antitumor activity. For example, the water extract of $M$. oleifera leaves is known to inhibit growth and induce apoptosis in lung cancer [14], liver cancer [15], oral cancer [29], pancreatic cancer [17], esophageal cancer [30], Ehrlich ascites carcinoma [31], and human melanoma cells [32]. The alcohol extract of $M$. oleifera leaves can inhibit cell growth and induce apoptosis and cell cycle arrest in breast cancer, colon cancer [33], leukemia [16], and cervical cancer [18] cells. The methanolic extract of $M$. oleifera leaves can inhibit cell growth and induce apoptosis and cell cycle arrest in cervical cancer [34] and prostate cancer [35] cells. Similarly, the phenolic extract of $M$. oleifera leaves can induce apoptosis in human melanoma cells [36]. In addition, the bark and seeds of $M$. oleifera also have antitumor activity $[33,37,38]$. These results demonstrated that $M$. oleifera has good antitumor activity against a variety of cancers; however, studies of $M$. oleifera have mainly assessed the antitumor activity of the crude extract.

As numerous studies have confirmed that alkaloids may be the main mediators of the antitumor activity of many plants, we extracted and prepared MOAE for the study of its anticancer activity. In this study, we found that MOAE caused a certain degree of inhibition on the growth of A549 


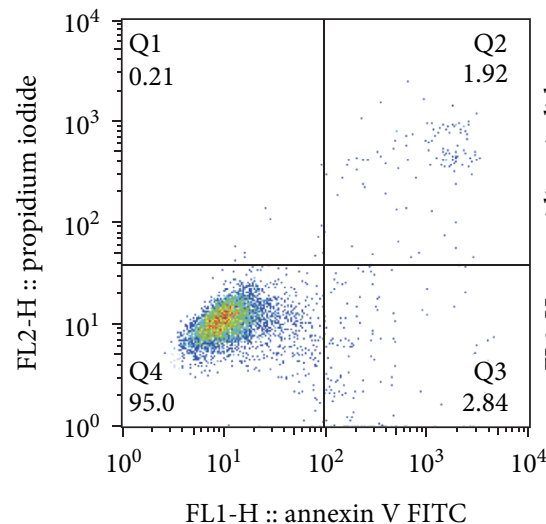

$\operatorname{MOAE}(\mu \mathrm{g} / \mathrm{mL}) \quad 0$

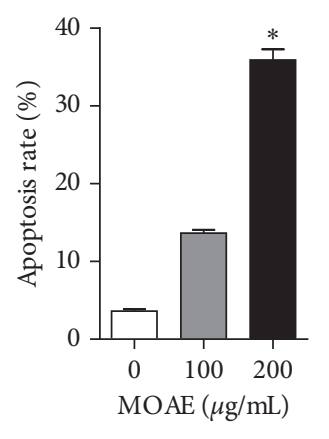

(b)

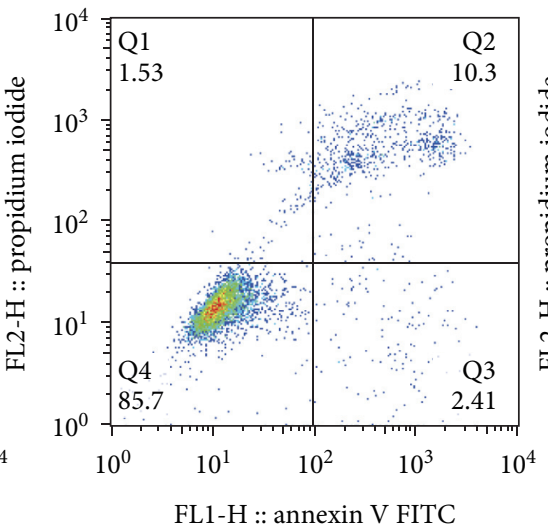

100

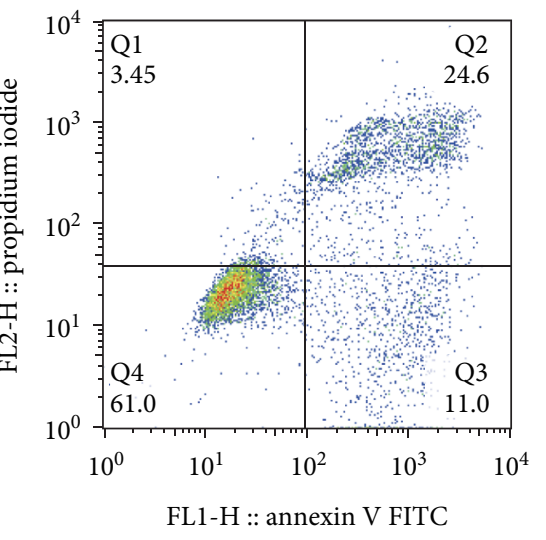

200

(a)

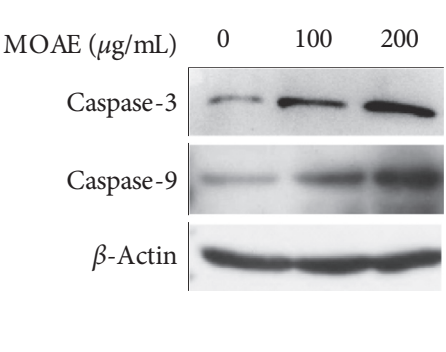

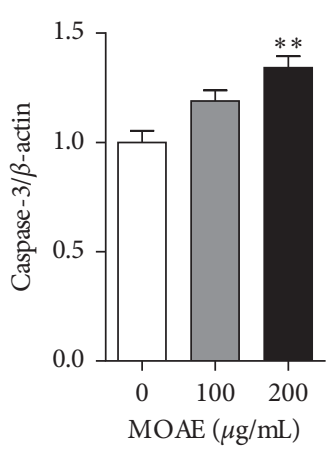

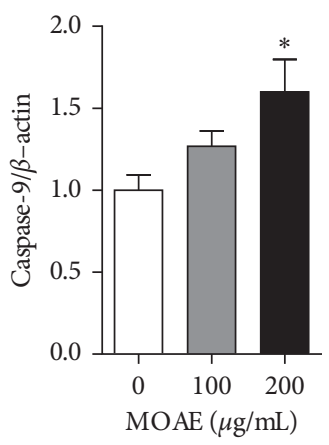

(c)

Figure 2: MOAE induces apoptosis in A549 cells. A549 cells were treated with MOAE (0, 100, or $200 \mu \mathrm{g} / \mathrm{mL})$ for $48 \mathrm{~h}$. (a) The percentage of apoptotic cells was determined by flow cytometry. (b) The percentage of apoptotic cells in each treatment group. (c) The expression of the apoptosis-related proteins caspase-3 and caspase-9 in A549 cells was measured by western blotting assay, with $\beta$-actin used as the loading control. Quantification of the relative levels of caspase- 3 and caspase- 9 proteins. The results are expressed as the mean \pm SEM of three independent experiments. ${ }^{*} p<0.05$ and ${ }^{* *} p<0.01$ vs. $0 \mu \mathrm{g} / \mathrm{mL}$.

cells, A375 cells, HCT116 cells, MDA-MB-231 cells, and Hep-G2 cells, with the strongest inhibitory activity in A549 cells. Of the four types of lung cancer cells tested, MOAE selectively inhibited the growth of A549 cells. In addition, we found that MOAE treatment could inhibit migration in A549 cells as well as induce apoptosis and cell cycle arrest. We also found that the underlying mechanism may be related to the inhibition of JAK2/STAT3 signaling pathway activation.

Hyperproliferation and blocked apoptosis are among the main features of tumor cells that play an important role in cancer occurrence and development. Consequently, inhibiting tumor cell proliferation and inducing apoptosis are the main strategies for tumor treatment. Caspase-3 and caspase9 are the major inducers of cell apoptosis through the promotion of DNA degradation and the formation of apoptotic bodies [39]. In this study, we found that MOAE treatment inhibited the proliferation of A549 cells in a concentration- and time-dependent manner. In addition, MOAE significantly induced apoptosis in A549 cells and increased the expression of caspase-3 and caspase-9.

An abundance of studies has found that M. oleifera can induce cell cycle arrest in various tumor cell types. For example, $M$. oleifera leaves and bark extracts induced significant G2/M phase arrest in MDA-MB-231 breast cancer cells and HCT-8 colon cancer cells [33]; water extracts of M. oleifera leaves induced cell cycle arrest in Hep-G2 cells by reducing the ratio of cells in the G1, S, and G2/M phases [40]; M. oleifera isothiocyanate [4- $(\alpha$-L-rhamnopyranosyloxy)benzyl $\mathrm{C}$ ] induced cell cycle arrest in human neuroblastoma SH-SY5Y cells by increasing the populations of cells in the G2 and S phase, decreasing the population of cells in the G1 phase, and increasing the expression of the protein p21 [41]; Hep-G2 cells treated with M. oleifera diethyl ether extracts and ethyl acetate extracts were arrested in the G2/M phase [42]; and finally, a leaf extract of $M$. oleifera induced cell cycle arrest in Panc-1 pancreatic cancer cells by increasing the population of cells in the subG1 phase [43]. In our study, MOAE treatment reduced the proportion of cells in the G1 phase and increased the number of cells in the $S$ phase, while decreasing the expression of cyclin D1 and cyclin E and increasing the expression of p21. Together, these results showed that MOAE could induce cell cycle arrest in A549 cells.

Tissue infiltration and distant metastasis are two other important biological phenotypes of tumor cells [44]. The 

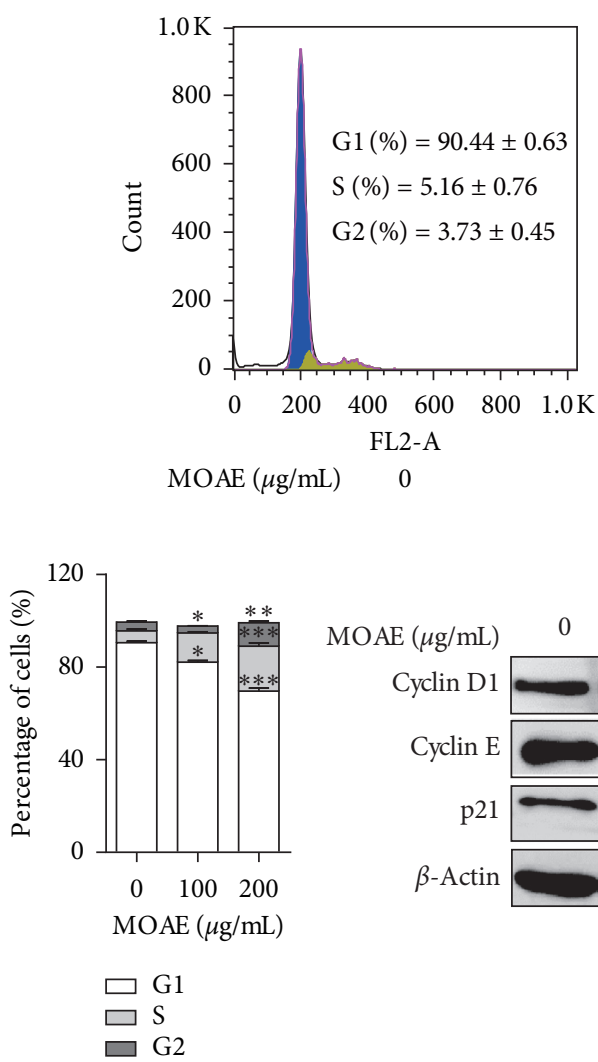

(b)

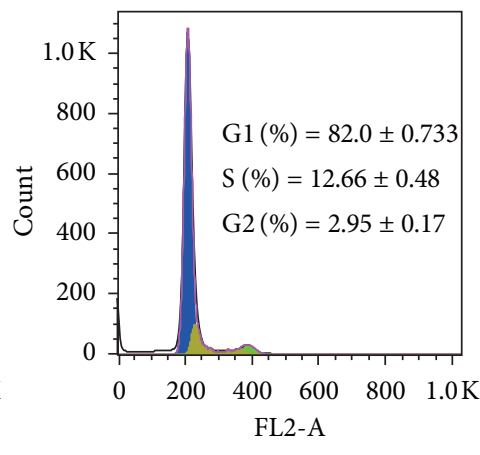

100

(a)
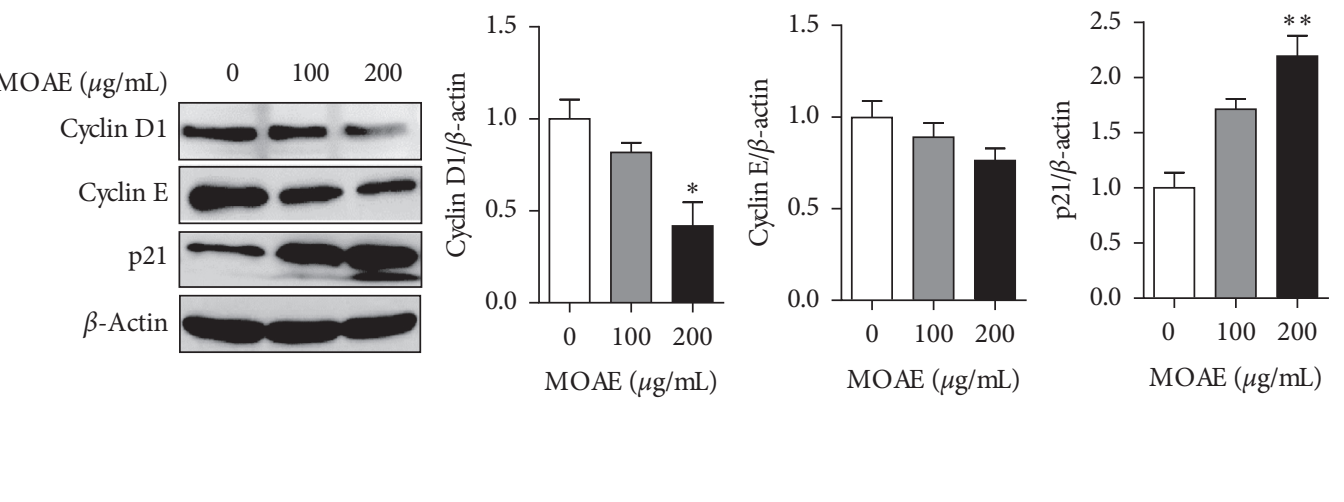

(c)

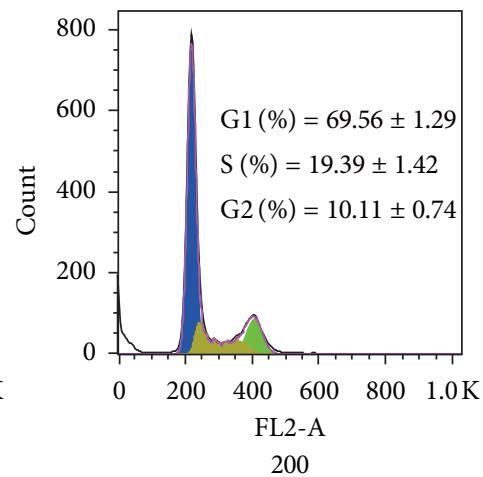

$\operatorname{MOAE}(\mu \mathrm{g} / \mathrm{mL})$

Figure 3: MOAE induces cell cycle arrest in A549 cells. A549 cells were treated with MOAE (0, 100, or $200 \mu \mathrm{g} / \mathrm{mL})$ for $48 \mathrm{~h}$. (a) The cell cycle of A549 cells was analyzed by flow cytometry; (b) statistical analysis of three independent experiments. (c) The expression of the cell cyclerelated proteins cyclin D1, cyclin E, and p21 in A549 cells was assessed by western blotting assay, with $\beta$-actin used as the loading control. Quantification of the relative levels of the proteins cyclin D1, cyclin E, and p21. The results are expressed as the mean \pm SEM of three independent experiments. ${ }^{*} p<0.05,{ }^{* *} p<0.01$, and ${ }^{* * *} p<0.001 v s .0 \mu \mathrm{g} / \mathrm{mL}$.

cause of death of most patients with NSCLC is not the primary lesions but the subsequent tumor metastases [45]. The MMPs are zinc ion-dependent endopeptidases that can degrade the extracellular matrix and vascular basement membrane; they play an important role in the invasion and metastasis of tumor cells by helping them to break through the basement membrane barrier [46]. Among the various members of the MMP family, MMP2 and MMP9 have major roles in cancer metastasis. Several studies have shown that inhibiting the expression of MMP2 or MMP9 can suppress the migration of A549 cells. For example, isolinderalactone inhibits A549 cell migration by downregulating MMP2 expression [47], whereas the ethanol extract of the leaves of Dillenia pentagyna suppresses the migration of A549 cells by decreasing the expression of MMP2 and MMP9 [48]. In addition, angelicin reduces the migratory capacity of A549 cells by reducing the expression of MMP2 and MMP9 [49]. In this study, we found that MOAE inhibited the migratory ability of A549 cells and decreased the protein expression of MMP2 and MMP9 in A549 cells.

The treatment strategies of NSCLC include surgery, radiation, chemotherapy, targeted therapy, or immunotherapy, either alone or in combination. However, approximately $80 \%$ of patients with NSCLC still develop stage
IV tumors, and the 5-year relative survival rate is less than $20 \%$. This may be related to tumor resistance during the treatment process, that is, the tumor's response to tyrosine kinase inhibitors (TKIs) or immune checkpoint blockers (ICBs) becomes impeded. Consequently, researchers have focused on alternative druggable targets in NSCLC to provide new therapies or improve existing treatments [50]. The JAK2/STAT3 signaling pathway is frequently activated in NSCLC and regulates a variety of cell functions, including proliferation, cell differentiation, metastasis, angiogenesis, apoptosis, and immune response; hence, STAT3 and its upstream activator JAK1/2 are considered promising targets [50-52]. Concurrently, studies have shown that STAT3 signaling mediates the resistance of NSCLC to EGFR-targeted therapies [53]. Therefore, the inhibition of JAK2/ STAT3 signal transduction is an effective strategy for NSCLC treatment. At present, studies have demonstrated that numerous phytochemicals can interfere with the JAK/ STAT signaling mechanism in human malignant cells, including phenolics, polyphenols, terpenoids, alkaloids, saponins, steroids, lignans, and phytoalexins [54]. Therefore, phytochemicals are a potential lung cancer treatment. In the present study, we found that MOAE decreased the levels of JAK2 and STAT3 phosphorylation in A549 cells, indicating 

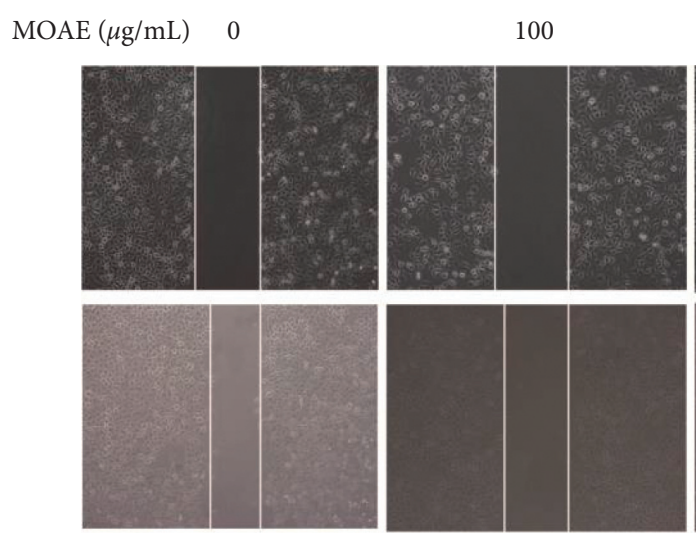

(a)

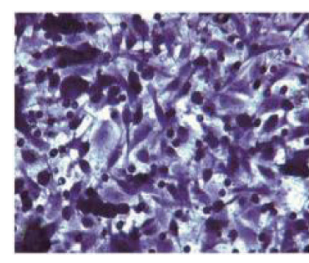

100

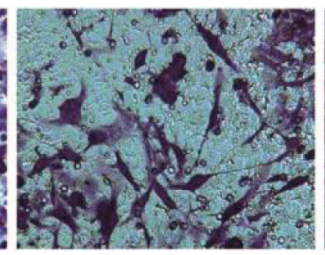

200

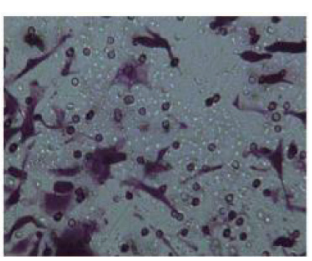

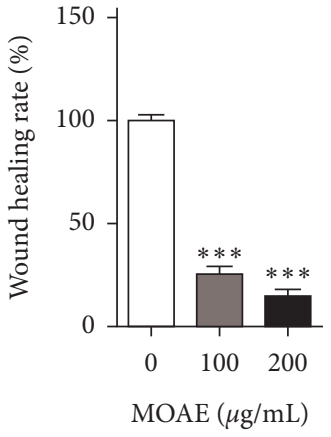

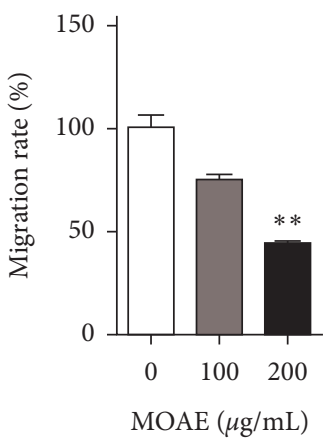

(b)
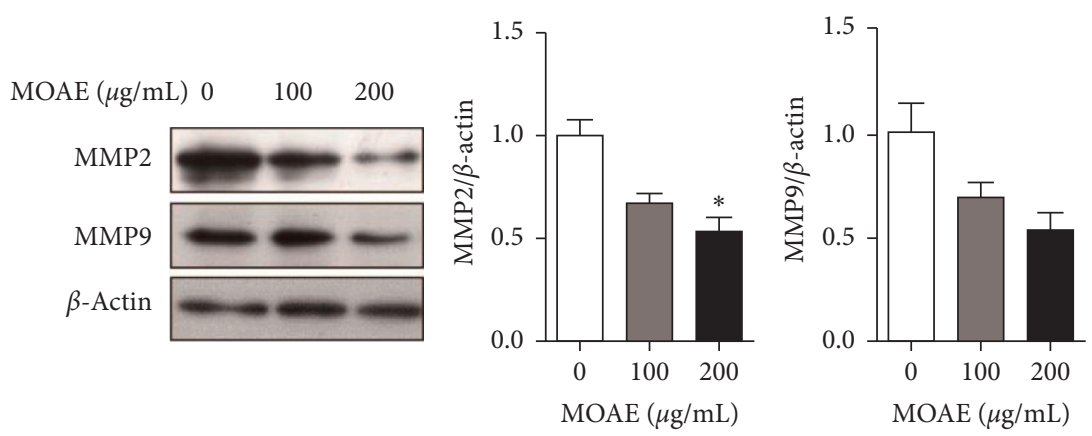

(c)

Figure 4: MOAE inhibits migration of A549 cells. A549 cells were treated with MOAE $(0,100$, or $200 \mu \mathrm{g} / \mathrm{mL})$ for $48 \mathrm{~h}$. The cell migration was assessed by (a) wound-healing and (b) Transwell migration assays. (c) The expression of the migration-related proteins MMP2 and MMP9 was measured by western blotting assay, with $\beta$-actin as the loading control. The results are expressed as the mean \pm SEM of three independent experiments. ${ }^{*} p<0.05,{ }^{* *} p<0.01$, and ${ }^{* * *} p<0.001 \mathrm{vs} .0 \mu \mathrm{g} / \mathrm{mL}$.

that MOAE could suppress the activation of the JAK2/ STAT3 signaling pathway. Furthermore, AZD1480 inhibited the proliferation and migration of A549 cells, and the effects of MOAE and AZD1480 were not additive, indicating that MOAE inhibited the proliferation and migration of A549 cells by suppressing the JAK2/STAT3 signaling pathway.

Although the current targeted therapies and personalized therapies for cancer have achieved remarkable success, the genetic heterogeneity of tumors, high costs, and high toxicity of treatments, among other issues, have severely restricted the treatment of cancer. Therefore, to solve these problems, scientists have proposed the concept of a low-toxicity "broad-spectrum" therapeutic approach [55]. This broad-spectrum treatment method involves the combination of a variety of low-toxicity drugs, including the use of plant- and food-derived chemicals that have been studied or used for cancer prevention and treatment. These combinations can collectively affect many pathways that are critical to the occurrence and spread of cancer. As these natural products are highly efficient and have low toxicity and low cost, they are widely favored. For example, it has been confirmed that many natural products, including resveratrol, epigallocatechin gallate (EGCG), curcumin, and lycopene, can induce tumor cell apoptosis and cell growth arrest. In addition, these natural products can be combined with synthetic drugs to exert synergistic effects; thus, they have potential clinical applications. $M$. oleifera leaves are eaten as a vegetable in countries such 


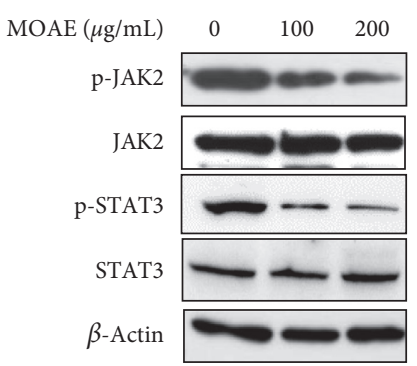

(a)

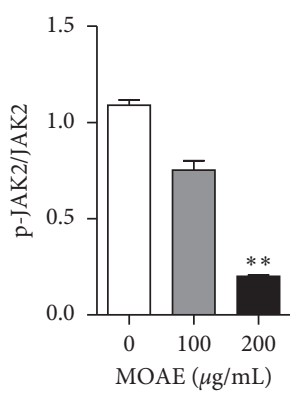

(b)

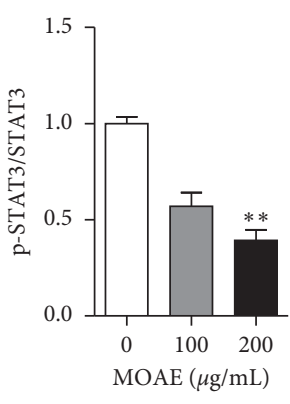

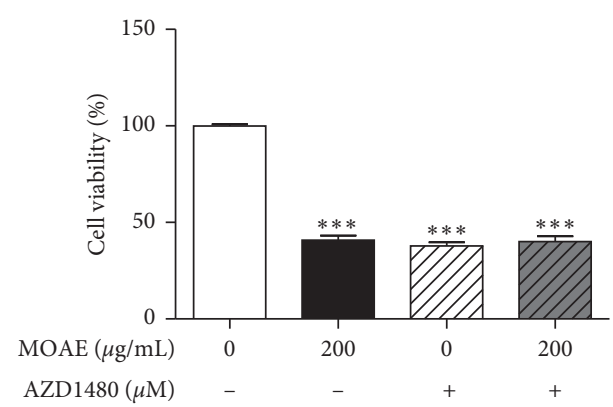

(c)

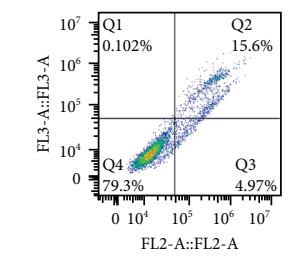

$\operatorname{MOAE}(\mu \mathrm{g} / \mathrm{mL}) \quad 0$ $\operatorname{AZD} 1480(\mu \mathrm{M}) \quad-$

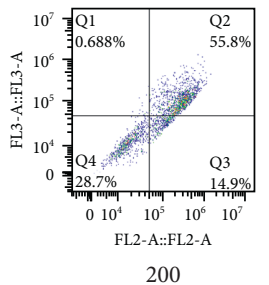

200

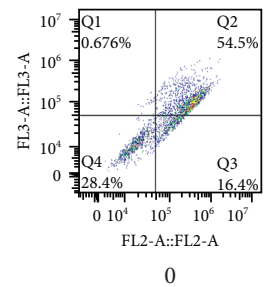

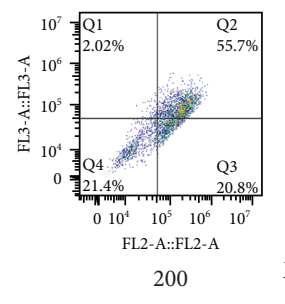

$+$

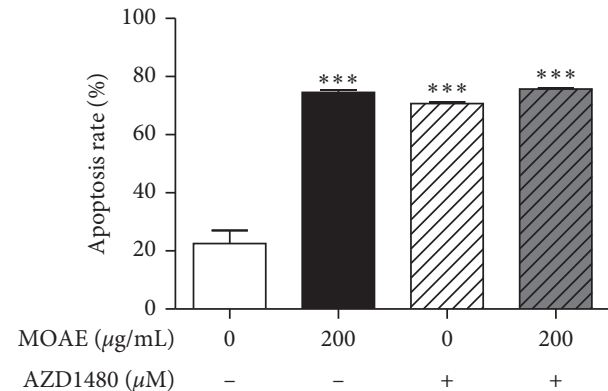

(d)
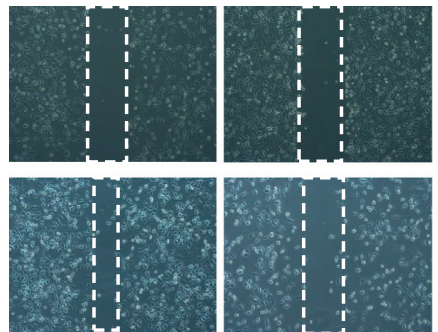

$\operatorname{MOAE}(\mu \mathrm{g} / \mathrm{mL}) \quad 0$ $\operatorname{AZD} 1480(\mu \mathrm{M}) \quad-$

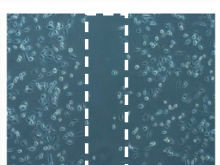

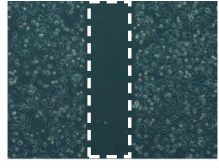

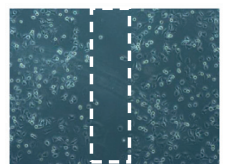

200
0

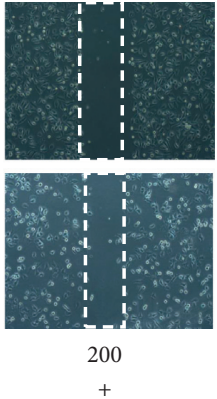

(e)

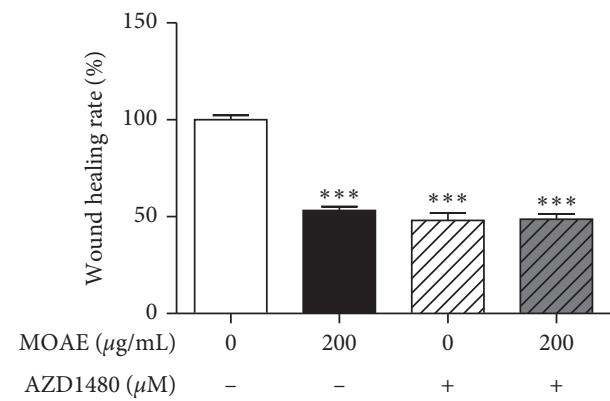

FIGURE 5: MOAE inhibits the activation of the JAK2/STAT3 signaling pathway in A549 cells. A549 cells were treated with MOAE (0, 100, or $200 \mu \mathrm{g} / \mathrm{mL}$ ) for $48 \mathrm{~h}$. (a) The protein expression of JAK2, p-JAK2, STAT3, and p-STAT3 was measured by western blotting assay, with $\beta$-actin used as the loading control. (b) Quantification of the relative levels of p-JAK2 and p-STAT3; each value was normalized to that of JAK2 and STAT3, respectively. Cell viability (c), cell apoptosis (d), and cell migration (e) were analyzed using the MTT assay, flow cytometry, and wound healing assay, respectively. A549 cells were pretreated for $2 \mathrm{~h}$ with AZD1480 $(2.5 \mu \mathrm{M})$ before treatment with MOAE $(0$ or $200 \mu \mathrm{g} / \mathrm{mL})$ for $48 \mathrm{~h}$. The results are expressed as the mean \pm SEM of three independent experiments. ${ }^{* *} p<0.01$ and ${ }^{* * *} p<0.001$ vs. $0 \mu \mathrm{g} / \mathrm{mL}$.

as China and India. In this study, we have confirmed that MOAE inhibits the growth and migration of A549 cells and does not strongly effect on the growth of GES-1 cells. Therefore, MOAE derived from edible plants is a candidate substance for the broad-spectrum therapeutic approach, which has the potential to be used in combination treatments.

Five alkaloids isolated from the leaves, stems, seeds, and roots of $M$. oleifer $a-N, \alpha$-L-rhamnopyranosyl vincosamide, $N$-benzylcarbamic acid, deoxy-niazimicin, 1, 3-dibenzyl urea, and aurantiamide acetate-exert protective effects against cardiovascular disease and can remove free radicals $[5,20,21]$. In this study, despite high-resolution mass spectrometric analysis of MOAE, we were unable to identify some of the highly abundant compounds present in the extract; therefore, further systematic analysis is needed to identify other bioactive components in MOAE. 

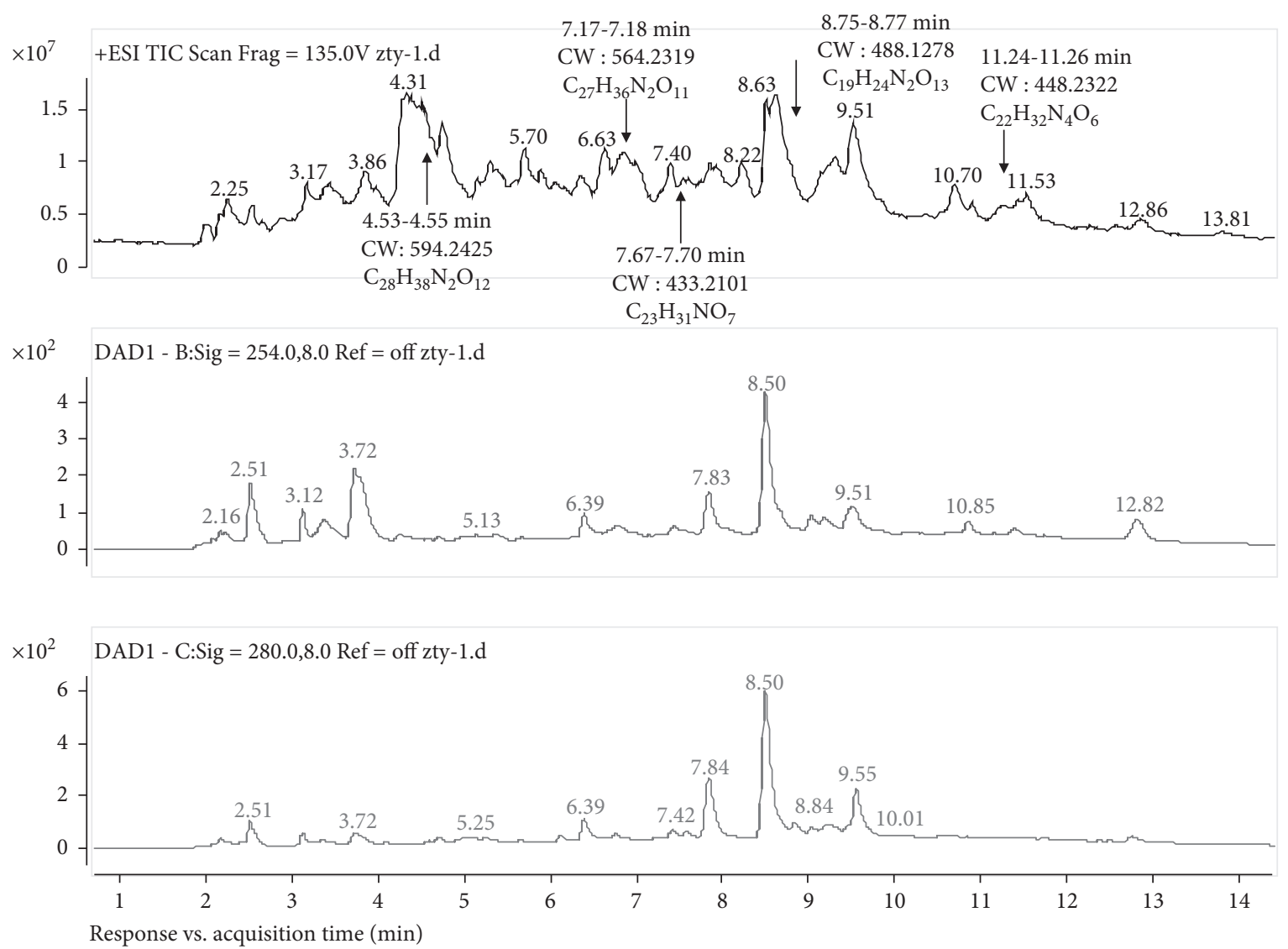

Figure 6: Analysis of the chemical constituents of MOAE using LTQ-Orbitrap mass spectrometry (MS). Total ion chromatogram of MOAE.

\section{Conclusions}

In conclusion, we demonstrated that MOAE exhibits potent inhibitory activity against the proliferative and migration of A549 cells, and we showed that MOAE could induce apoptosis and cell cycle arrest in A549 cells. Collectively, our results suggested that these effects of MOAE may be mediated through the inhibition of JAK2/STAT3 signaling pathway activation.

\section{Data Availability}

The data used to support the findings of this study are included within the article. Other data used to support the findings of this study are available from the corresponding author upon request.

\section{Disclosure}

The funding body had no role in the design of the study, collection, analysis, and interpretation of data, or writing of the manuscript.

\section{Conflicts of Interest}

The authors declare that there are no conflicts of interest regarding the publication of this paper.

\section{Authors' Contributions}

JX and L-JP contributed equally to this work. JS and YT designed the study. JX, L-JP, M-RY, W-WJ, J-YM, and C-YS performed the experiments. YT and JX wrote the paper. All authors reviewed the final manuscript.

\section{Acknowledgments}

This work was supported by the Major Project of the Science and Technology Department of Yunnan Province (202002AA100005), YEFICRC Project of Yunnan Provincial Key Programs (2019ZG009), Yunnan Province Young and Middle-Aged Academic and Technical Leaders Reserve Talents Project (2018HB040), and Science and Technology Planning Project of Yunnan Provincial Science and Technology Department (2018FG001-088).

\section{References}

[1] M. C. Roach, C. G. Robinson, T. A. Dewees et al., "Stereotactic body radiation therapy for central early-stage NSCLC: results of a prospective phase I/II trial," Journal of Thoracic Oncology, vol. 13, no. 11, pp. 1727-1732, 2018.

[2] P. E. Postmus, K. M. Kerr, M. Oudkerk et al., "Early and locally advanced non-small-cell lung cancer (NSCLC): ESMO Clinical Practice Guidelines for diagnosis, treatment and follow-up," Annals of Oncology, vol. 28, no. Suppl 4, pp. iv1-iv21, 2017. 
[3] J.-C. Soria, Y.-L. Wu, K. Nakagawa et al., "Gefitinib plus chemotherapy versus placebo plus chemotherapy in EGFRmutation-positive non-small-cell lung cancer after progression on first-line gefitinib (IMPRESS): a phase 3 randomised trial," The Lancet Oncology, vol. 16, no. 8, pp. 990-998, 2015.

[4] S. Cheenpracha, E.-J. Park, W. Y. Yoshida et al., "Potential anti-inflammatory phenolic glycosides from the medicinal plant Moringa oleifera fruits," Bioorganic \& Medicinal Chemistry, vol. 18, no. 17, pp. 6598-6602, 2010.

[5] S. Panda, A. Kar, P. Sharma, and A. Sharma, "Cardioprotective potential of N, $\alpha$-l-rhamnopyranosyl vincosamide, an indole alkaloid, isolated from the leaves of Moringa oleifera in isoproterenol induced cardiotoxic rats: in vivo and in vitro studies," Bioorganic \& Medicinal Chemistry Letters, vol. 23, no. 4, pp. 959-962, 2013.

[6] K. Mehta, R. Balaraman, A. H. Amin, P. A. Bafna, and O. D. Gulati, "Effect of fruits of Moringa oleifera on the lipid profile of normal and hypercholesterolaemic rabbits," Journal of Ethnopharmacology, vol. 86, no. 2-3, pp. 191-195, 2003.

[7] M. Mbikay, "Therapeutic potential of Moringa oleifera leaves in chronic hyperglycemia and dyslipidemia: a review," Frontiers in Pharmacology, vol. 3, p. 24, 2012.

[8] R. Gupta, G. M. Kannan, M. Sharma, and S. J. Flora, "Therapeutic effects of Moringa oleifera on arsenic-induced toxicity in rats," Environmental Toxicology and Pharmacology, vol. 20, no. 3, pp. 456-464, 2005.

[9] S. G. Mahajan and A. A. Mehta, "Inhibitory action of ethanolic extract of seeds ofMoringa oleiferaLam. On systemic and local anaphylaxis," Journal of Immunotoxicology, vol. 4, no. 4, pp. 287-294, 2007.

[10] R. Ganguly and D. Guha, "Alteration of brain monoamines \& EEG wave pattern in rat model of Alzheimer's disease \& protection by Moringa oleifera," The Indian Journal of Medical Research, vol. 128, no. 6, pp. 744-751, 2008.

[11] S. A. Sharifudin, S. Fakurazi, M. T. Hidayat, I. Hairuszah, M. Aris Mohd Moklas, and P. Arulselvan, "Therapeutic potential ofMoringa oleiferaextracts against acetaminopheninduced hepatotoxicity in rats," Pharmaceutical Biology, vol. 51, no. 3, pp. 279-288, 2013.

[12] A. F. S. Santos, A. C. C. Argolo, P. M. G. Paiva, and L. C. B. B. Coelho, "Antioxidant activity of Moringa oleifera tissue extracts," Phytotherapy Research, vol. 26, no. 9, pp. 1366-1370, 2012.

[13] M. M. Rahman, M. M. Rahman, S. Akhter et al., "Control of coliform bacteria detected from diarrhea associated patients by extracts of Moringa oleifera," Nepal Medical College Journal: NMCJ, vol. 12, no. 1, pp. 12-19, 2010.

[14] C. Tiloke, A. Phulukdaree, and A. A. Chuturgoon, "The antiproliferative effect of Moringa oleifera crude aqueous leaf extract on cancerous human alveolar epithelial cells," BMC Complementary and Alternative Medicine, vol. 13, no. 1, p. 226, 2013.

[15] I. L. Jung, J. H. Lee, and S. C. Kang, “A potential oral anticancer drug candidate, Moringa oleifera leaf extract, induces the apoptosis of human hepatocellular carcinoma cells," Oncology Letters, vol. 10, no. 3, pp. 1597-1604, 2015.

[16] E. O. Akanni, A. L. Adedeji, O. T. Adedosu, O. I. Olaniran, and J. K. Oloke, "Chemopreventive and anti-leukemic effects of ethanol extracts of Moringa oleifera leaves on wistar rats bearing benzene induced leukemia," Current Pharmaceutical Biotechnology, vol. 15, no. 6, pp. 563-568, 2014.

[17] B. Liron, E. Gideon, R. Ilan, R. Adam, V. Akiva, and L. A. Shahar, "Moringa Oleifera aqueous leaf extract downregulates nuclear factor-kappaB and increases cytotoxic effect of chemotherapy in pancreatic cancer cells," Bmc Complementary \& Alternative Medicine, vol. 13, no. 1, pp. 1-7, 2013.

[18] S. E. Atawodi, J. C. Atawodi, G. A. Idakwo et al., "Evaluation of the polyphenol content and antioxidant properties of methanol extracts of the leaves, stem, and root barks ofMoringa oleiferaLam," Journal of Medicinal Food, vol. 13, no. 3, pp. 710-716, 2010.

[19] C. Liu, S. Yang, K. Wang et al., "Alkaloids from traditional Chinese medicine against hepatocellular carcinoma," Biomedicine \& Pharmacotherapy, vol. 120, Article ID 109543, 2019.

[20] G.-F. Chen, M.-L. Yang, P.-C. Kuo, M.-C. Lin, and M.-Y. Liao, "Chemical constituents of Moringa oleifera and their cytotoxicity against doxorubicin-resistant human breast cancer cell lines (Mcf-7/Adr)," Chemistry of Natural Compounds, vol. 50, no. 1, pp. 175-178, 2014.

[21] F. Nikkon, A. S. Zahangir, and M. E. A. Habibur Rahman, "In vitro antimicrobial activity of the compound isolated from chloroform extract of moringa oleifera Lam," Pakistan Journal of Biological Sciences, vol. 6, no. 22, pp. 1888-1890, 2003.

[22] W. P. Jones and A. D. Kinghorn, "Extraction of plant secondary metabolites," Methods in Molecular Biology, vol. 864, pp. 341-366, 2012.

[23] X. Chen, J. Du, R. Jiang, and L. Li, "MicroRNA-214 inhibits the proliferation and invasion of lung carcinoma cells by targeting JAK1," American Journal of Translational Research, vol. 10, no. 4, pp. 1164-1171, 2018.

[24] J. S. Tong, Q. H. Zhang, X. Huang et al., "Icaritin causes sustained ERK1/2 activation and induces apoptosis in human endometrial cancer cells," PLoS One, vol. 6, no. 3, p. e16781, 2011.

[25] M. Zang, Y. Zhang, B. Zhang et al., "CEACAM6 promotes tumor angiogenesis and vasculogenic mimicry in gastric cancer via FAK signaling," Biochimica et biophysica acta, vol. 1852, no. 5, pp. 1020-1028, 2015.

[26] T. Sithara, B. P. Dhanya, K. B. Arun et al., "Zerumbone, a cyclic sesquiterpene from zingiber zerumbet induces apoptosis, cell cycle arrest, and antimigratory effects in SW480 colorectal cancer cells," Journal of Agricultural and Food Chemistry, vol. 66, no. 3, pp. 602-612, 2018.

[27] Y. Zhang, S. He, R. Mei et al., "miR-29a suppresses IL-13induced cell invasion by inhibiting YY1 in the AKT pathway in lung adenocarcinoma A549 cells," Oncology Reports, vol. 39, no. 6, pp. 2613-2623, 2018.

[28] M. Zhao, F.-H. Gao, J.-Y. Wang et al., "JAK2/STAT3 signaling pathway activation mediates tumor angiogenesis by upregulation of VEGF and bFGF in non-small-cell lung cancer," Lung Cancer, vol. 73, no. 3, pp. 366-374, 2011.

[29] S. Sreelatha, A. Jeyachitra, and P. R. Padma, "Antiproliferation and induction of apoptosis by Moringa oleifera leaf extract on human cancer cells," Food and Chemical Toxicology, vol. 49, no. 6, pp. 1270-1275, 2011.

[30] C. Tiloke, A. Phulukdaree, and A. A. Chuturgoon, "The antiproliferative effect ofMoringa oleiferaCrude aqueous leaf extract on human esophageal cancer cells," Journal of Medicinal Food, vol. 19, no. 4, pp. 398-403, 2016.

[31] D. Barhoi, P. Upadhaya, S. N. Barbhuiya, A. Giri, and S. Giri, "Aqueous extract of Moringa oleifera exhibit potential anticancer activity and can be used as a possible cancer therapeutic agent: a study involving in vitro and in vivo approach," Journal of the American College of Nutrition, vol. 40, pp. 1-16, 2020. 
[32] B. H. Do, T. P. T. Nguyen, N. Q. C. Ho, T. L. Le, N. S. Hoang, and C. C. Doan, "Mitochondria-mediated Caspase-dependent and Caspase-independent apoptosis induced by aqueous extract from Moringa oleifera leaves in human melanoma cells," Molecular Biology Reports, vol. 47, no. 5, pp. 3675-3689, 2020.

[33] A. K. Al-Asmari, S. M. Albalawi, M. T. Athar, A. Q. Khan, H. Al-Shahrani, and M. Islam, "Moringa oleifera as an anticancer agent against breast and colorectal cancer cell lines," PLoS One, vol. 10, no. 8, p. e0135814, 2015.

[34] P. Pandey and F. Khan, "Jab1 inhibition by methanolic extract of moringa oleifera leaves in cervical cancer cells: a potent targeted therapeutic approach," Nutrition and Cancer, pp. 1-9, 2020, inprint.

[35] F. Khan, P. Pandey, V. Ahmad, and T. K. Upadhyay, "Moringa oleifera methanolic leaves extract induces apoptosis and G0/ G1 cell cycle arrest via downregulation of Hedgehog Signaling Pathway in human prostate PC-3 cancer cells," Journal of Food Biochemistry, vol. 44, no. 8, p. e13338, 2020.

[36] B. H. Do, N. S. Hoang, T. P. T. Nguyen, N. Q. C. Ho, T. L. Le, and C. C. Doan, "Phenolic extraction of moringa oleifera leaves induces caspase-dependent and caspase-independent apoptosis through the generation of reactive oxygen species and the activation of intrinsic mitochondrial pathway in human melanoma cells," Nutrition and Cancer, vol. 73, pp. 1-20, 2020.

[37] S. Budda, C. Butryee, S. Tuntipopipat et al., "Suppressive effects of Moringa oleifera Lam pod against mouse colon carcinogenesis induced by azoxymethane and dextran sodium sulfate," Asian Pacific Journal of Cancer Prevention: APJCP, vol. 12, no. 12, pp. 3221-3228, 2011.

[38] K. A. Diab, S. K. Guru, S. Bhushan, and A. K. Saxena, "In in vitro anticancer activities of anogeissus latifolia, Terminalia bellerica, Acacia catechu and moringa oleiferna Indian plants," Asian Pacific Journal of Cancer Prevention, vol. 16, no. 15, pp. 6423-6428, 2015.

[39] Y. Shi, "Mechanisms of caspase activation and inhibition during apoptosis," Molecular Cell, vol. 9, no. 3, pp. 459-470, 2002.

[40] C. Tiloke, A. Phulukdaree, R. M. Gengan, and A. A. Chuturgoon, "Moringa oleiferaAqueous leaf extract induces cell-cycle arrest and apoptosis in human liver hepatocellular carcinoma cells," Nutrition and Cancer, vol. 71, no. 7, pp. 1165-1174, 2019.

[41] S. Cirmi, N. Ferlazzo, A. Gugliandolo et al., "Moringin from moringa oleifera seeds inhibits growth, arrests cell-cycle, and induces apoptosis of SH-SY5Y human neuroblastoma cells through the modulation of NF- $\kappa \mathrm{B}$ and apoptotic related factors," International Journal of Molecular Sciences, vol. 20, no. 8, 2019.

[42] M. Mansour, M. F. Mohamed, A. Elhalwagi, H. A. El-Itriby, H. H. Shawki, and I. A. Abdelhamid, "Moringa peregrina leaves extracts induce apoptosis and cell cycle arrest of hepatocellular carcinoma," BioMed Research International, vol. 2019, Article ID 2698570, 13 pages, 2019.

[43] L. Berkovich, G. Earon, I. Ron, A. Rimmon, A. Vexler, and S. Lev-Ari, "Moringa Oleifera aqueous leaf extract downregulates nuclear factor-kappaB and increases cytotoxic effect of chemotherapy in pancreatic cancer cells," BMC Complementary and Alternative Medicine, vol. 13, p. 212, 2013.

[44] D. Liu, X. Feng, X. Wu et al., "Tumor suppressor in lung cancer 1 (TSLC1), a novel tumor suppressor gene, is implicated in the regulation of proliferation, invasion, cell cycle, apoptosis, and tumorigenicity in cutaneous squamous cell carcinoma," Tumor Biology, vol. 34, no. 6, pp. 3773-3783, 2013.

[45] X. Deng, Q. Ma, B. Zhang, H. Jiang, Z. Zhang, and Y. Wang, "Migration-stimulating factor (MSF) is over-expressed in non-small cell lung cancer and promotes cell migration and invasion in A549 cells over-expressing MSF," Experimental Cell Research, vol. 319, no. 17, pp. 2545-2553, 2013.

[46] A. Jabłońska-Trypuć, M. Matejczyk, and S. Rosochacki, "Matrix metalloproteinases (MMPs), the main extracellular matrix (ECM) enzymes in collagen degradation, as a target for anticancer drugs," Journal of Enzyme Inhibition and Medicinal Chemistry, vol. 31pp. 177-183, sup1, 2016.

[47] C. H. Chuang, L. Y. Wang, Y. M. Wong, and E. S. Lin, “Antimetastatic effects of isolinderalactone via the inhibition of MMP-2 and up regulation of NM23-H1 expression in human lung cancer A549 cells," Oncology Letters, vol. 15, no. 4, pp. 4690-4696, 2018.

[48] D. De, P. Chowdhury, S. K. Panda, and U. Ghosh, "Ethanolic extract of leaf of Dillenia pentagyna reduces in-vitro cell migration and induces intrinsic pathway of apoptosis via downregulation of NF- $\kappa \beta$ in human NSCLC A549 cells," Journal of Cellular Biochemistry, vol. 120, no. 12, pp. 1984119857, 2019.

[49] G. Li, Y. He, J. Yao et al., “Angelicin inhibits human lung carcinoma A549 cell growth and migration through regulating JNK and ERK pathways," Oncology Reports, vol. 36, no. 6, pp. 3504-3512, 2016.

[50] J. Mohrherr, I. Z. Uras, H. P. Moll, and E. Casanova, "STAT3: versatile functions in non-small cell lung cancer," Cancers (Basel), vol. 12, no. 5, 2020.

[51] E. B. Haura, J. Turkson, and R. Jove, "Mechanisms of disease: insights into the emerging role of signal transducers and activators of transcription in cancer," Nature Clinical Practice Oncology, vol. 2, no. 6, pp. 315-324, 2005.

[52] J. H. Lee, C. Kim, S. G. Lee, G. Sethi, and K. S. Ahn, "Ophiopogonin D, a steroidal glycoside abrogates STAT3 signaling cascade and exhibits anti-cancer activity by causing GSH/GSSG imbalance in lung carcinoma," Cancers (Basel), vol. 10, no. 11, 2018.

[53] A. A. Zulkifli, F. H. Tan, T. L. Putoczki, S. S. Stylli, and R. B. Luwor, "STAT3 signaling mediates tumour resistance to EGFR targeted therapeutics," Molecular and Cellular Endocrinology, vol. 451, pp. 15-23, 2017.

[54] S. Bose, S. Banerjee, A. Mondal et al., "Targeting the JAK/ STAT signaling pathway using phytocompounds for cancer prevention and therapy," Cells, vol. 9, no. 6, 2020.

[55] K. I. Block, C. Gyllenhaal, L. Lowe et al., "Designing a broadspectrum integrative approach for cancer prevention and treatment," Seminars in Cancer Biology, vol. 35, no. Suppl, pp. S276-s304, 2015. 